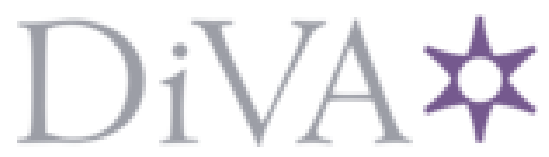

http://www.diva-portal.org

This is the published version of a paper published in Arctic.

Citation for the original published paper (version of record):

Keskitalo, E., Malmberg, G., Westin, K., Wiberg, U., Müller, D. et al. (2013)

Contrasting Arctic and Mainstream Swedish Descriptions of Northern Sweden: The View from

Established Domestic Research.

Arctic, 66(3): 351-365

Access to the published version may require subscription.

N.B. When citing this work, cite the original published paper.

Permanent link to this version:

http://urn.kb.se/resolve?urn=urn:nbn:se:umu:diva- 82515 


\title{
Contrasting Arctic and Mainstream Swedish Descriptions of Northern Sweden: The View from Established Domestic Research
}

\author{
E.C.H. KESKITALO, ${ }^{1,2}$ G. MALMBERG, ${ }^{1}$ K. WESTIN, ${ }^{1}$ U. WIBERG,${ }^{1}$ D.K. MÜLLER ${ }^{1}$ and Ö. PETTERSSON ${ }^{1}$
}

(Received 19 June 2012; accepted in revised form 8 January 2013)

\begin{abstract}
In 2011, Sweden released its first-ever Arctic strategy, in preparation for taking over the chairmanship of the Arctic Council, an eight-state cooperation organization. The recent political development that will include Sweden more extensively in Arctic regional cooperation makes it relevant to review and comment on the image of the areas involved from a Swedish viewpoint and to improve the often very brief descriptions of northernmost Sweden in Arctic literature. In this paper, we contrast descriptions of the Arctic in the Arctic Human Development Report (AHDR) with descriptions of northern Sweden in established domestic demographic and regional development research. The study shows that many of the assumptions in the first AHDR to the effect that the eight "Arctic" regions are rather directly comparable in fact reveal substantial differences between areas, with northern Sweden standing in sharp contrast to many of the descriptions. Instead of having a population that is very small, young, and rapidly growing because of a high birth rate, northern Sweden is characterized by relatively dense habitation with a stable and aging population of long-term residents. Moreover, it has a very small and relatively integrated indigenous population with largely the same health situation as in Sweden overall. While depopulation and urbanization are evident in its less populated areas, migration from the region is partly directed at the larger regional centres in the area, following a pattern seen in the Western world at large.
\end{abstract}

Key words: Arctic, Sweden, Arctic Human Development Report, demography, economic development

RÉSUMÉ. En 2011, au moment où elle se préparait à assumer la présidence du Conseil de l'Arctique, un organisme de collaboration entre huit pays, la Suède a mis en œuvre sa toute première politique relative à l'Arctique. L'événement politique récent qui a fait en sorte que la Suède devra jouer un rôle plus grand dans la collaboration régionale de l'Arctique incite à analyser l'image des régions qui entrent en jeu du point de vue de la Suède, à porter des commentaires sur cette image ainsi qu'à améliorer les descriptions souvent très brèves de la partie la plus au nord de la Suède que l'on retrouve dans la documentation au sujet de l'Arctique. Dans cet article, nous contrastons les descriptions de l'Arctique figurant dans l'Arctic Human Development Report (AHDR) avec les descriptions du nord de la Suède émanant de travaux de recherche établis sur le développement régional et la démographie intérieure. Cette étude permet de constater que de nombreuses hypothèses du premier rapport AHDR selon lesquelles les huit régions " arctiques » sont plutôt directement comparables révèlent en fait des différences considérables entre les régions, le nord de la Suède représentant un contraste marqué par rapport à grand nombre des autres descriptions. Au lieu d'être doté d'une population très petite, jeune et en croissance rapide attribuable à un taux de natalité élevé, le nord de la Suède est caractérisé par une habitation relativement dense et une population stable et vieillissante composée de résidents de longue date. Par ailleurs, le nord de la Suède comprend une population indigène très petite et relativement intégrée affichant à peu près la même situation de santé que l'ensemble de la Suède. Bien que le dépeuplement et l'urbanisation s'avèrent évidents dans les zones moins peuplées, la migration en partance de cette région est partiellement orientée vers les plus grands centres régionaux de la région, conformément à la tendance générale enregistrée dans le monde occidental.

Mots clés : Arctique, Suède, Arctic Human Development Report, démographie, développement économique

Traduit pour la revue Arctic par Nicole Giguère.

\section{INTRODUCTION}

On 12 May 2011, Sweden released its first Arctic strategy (Swedish Department of Foreign Affairs, 2011) in preparation for assuming the chairmanship of the Arctic Council, an eight-state cooperation organization. The Arctic Council, formed in 1996 on a Canadian initiative, was largely motivated by a wish to normalize tensions in the area after the end of the Cold War (Keskitalo, 2004). In addition to the United States (Alaska), Canada, and Russia, the Arctic Council includes the Nordic countries. Today, the development of Sweden's Arctic policy is largely a result of the recent interest in the Arctic at the EU level, occasioned by the fact that climate change in the Arctic is opening up new oil and gas exploration areas and transport routes. These possibilities have led to a new "scramble for the Arctic,"

\footnotetext{
${ }^{1}$ Department of Geography and Economic History, Umeå University, 90187 Umeå, Sweden.

${ }^{2}$ Corresponding author: Carina.Keskitalo@geography.umu.se

(C) The Arctic Institute of North America
} 
resulting in, among other things, internal meetings by the five littoral states (Norway, Canada, the United States, Russia, and Denmark-Greenland) as well as sovereignty claims in the area (e.g., Crawford et al., 2008; Granholm and Kiesow, 2010). As a result, the EU-and subsequently also Sweden, thus far a rather silent partner in Arctic cooperation-have taken stances to motivate their inclusion in cooperation and thereby their ability to have a say in development in the area (e.g., EC, 2008).

In its Arctic strategy document, Sweden recognizes the consensus in the Arctic Council that areas at least down to the Arctic Circle should be seen as part of the Arctic (AMAP, 1998; Swedish Department of Foreign Affairs, 2011). This delineation, of course, also supports a relatively strong role for Sweden and the EU role in Arctic policy, as it includes areas of several EU member states. Broader definitions of the "Arctic" area exist, however, for instance in the Arctic Human Development Report (AHDR, 2004) and in the Barents Euro-Arctic Council, which includes northern Norway, Sweden, Finland, and northwest Russia (Swedish Chair of the Barents Euro-Arctic Council, 2009). The AHDR includes all of Norrbotten (the northernmost county of Sweden) and in some cases, such as the chapter on economic systems, Västerbotten, the second most northern county as well (AHDR, 2004), whereas the Barents Euro-Arctic Council includes the two counties in full (Swedish Chair of the Barents Euro-Arctic Council, 2009). In recent years, new transnational collaboration has been initiated. The Northern Sparsely Populated Areas (NSPA) cover the four northernmost provinces in Norway, the four northernmost counties in Sweden (including Norrbotten and Västerbotten), and six regions in northern and eastern Finland. The focus is to promote the NSPA on a European level and to highlight similarities and challenges within the region they form, such as their low population densities and relatively rich natural resources (NSPA, 2012).

It is against this background that it has become relevant to review current conceptions of the Arctic from a Swedish perspective, not least to improve and if necessary revise the often very brief descriptions of Sweden in Arctic literature such as the AHDR. Descriptions of the Arctic in which Canadian and traditional "Arctic" issues have dominated or set the agenda have to a large extent centered on environmental considerations and traditional indigenous subsistence (Keskitalo, 2004), although they do recognize that areas more recently included as "Arctic" through political cooperation possess other characteristics. Domestically in Sweden, however, descriptions of the country's "Arctic" area are not common, perhaps because even its northernmost tip is only sub-Arctic. Descriptions of areas in Sweden as "northern"- - with content very different from that found in international Arctic discourse (Keskitalo, 2004)are sometimes also applied to all of the five northernmost counties.

To determine how regions in Sweden compare with descriptions in Arctic literature, this paper challenges the images of the Arctic depicted in the AHDR (2004) through descriptions of northern Sweden in established domestic demographic and regional development research. It thereby aims to contribute to a better-informed image of the areas recently included as "Arctic" in different types of cooperation.

\section{THEORETICAL FRAMEWORK}

The Arctic has previously been treated as an area developed through region-building (Keskitalo, 2004). Drawing on an inherently critical perspective on region-building (Neumann, 1996, 1999), the constructed nature of regions is highlighted. Region-building, like nation-building, creates a region by developing an image of the region and cultivating this image in literature and knowledge-production activities. These activities produce written reports; representations, such as maps, that present a new region; symbols that present the region as a unitary entity; and forms of organization that reinforce the selection and description of the territory, with a view to establishing it as a coherent spatial entity in the minds of a wider public (e.g., Paasi, 1996). For the Arctic region, these activities and symbols may be said to include the development of an eight-state Arctic Council as an organization and a symbol; reports reinforcing the Council's selection of focal areas and topics, such as the Arctic Human Development Report; and the use of a map projection centered on the Arctic Ocean (Keskitalo, 2004).

Those who view development as region building understand descriptions of a region as discourse: they argue that neither the selection of an area as such nor the descriptions of peoples within an area can be seen as natural or as a given, but rather that the region is developed and constructed for political reasons (Anderson, 1991; Neumann, 1999). The concept of region building is not based on any assumption about the level at which regional development is constructed, in contrast to regionalism (seeing development as proceeding from below by popular forces), and regionalization (seeing development as proceeding from above through the work of decision makers, without relation to the populace at large). For instance, Aalbu and Wiberg (1997) discuss the creation of Barents Region cooperation and the challenging task of combining the top-down push of regionalization, characterized by nation-state policy-making with strategy and action plans for a dynamic transnational regional growth process, with a bottom-up perspective. The assumption behind region-building is that regional development is politically constructed among potentially different forces (such as different interest groups, local groups, and decision makers) whose positions resonate with the discourse on the region, and who in different ways stand to profit from that discourse. The discourse is a mode of description that includes certain perspectives and excludes others (Foucault, 1974); thus it is based on the selection of particular traits and has an exclusionary and specific political character (Neumann, 1999). 
This process of selection can be seen as resulting in descriptive violence. Nation-building processes have often aimed at creating one national identity to the exclusion of others. Similarly, the processes of building territorial entities require that the existence of an entity be justified through traits often described as essential (that is, as representing the "real" conditions), to the exclusion of other, potentially equally prevalent conditions (e.g., Anderson, 1991). A famous description of territorial processes resulting in descriptive violence is the case of the Orient (Said, 1979; cf. Jansson, 2003), in which Orientals were described in order to develop a counterpoint to the "civilized" characteristics claimed by the Occidentals, who were developing the descriptions. Over time, descriptive processes of creating a concept of the Arctic have relied largely on outside descriptions, in this case, those embedded in the understandings of the frontier (Keskitalo, 2004). Most famously described for the western expansion of the United States, but also relevant in conceptions of the Arctic, the frontier has been conceived of as the distinguishing line between culture and nature, civilization, and the environment. The position of culture and civilization was claimed by those developing the descriptions, those whose imperialistic intrusion into other lands was seen as pushing the frontier ahead of themselves. Through this descriptive logic, the lands claimed, which were largely conceived of as wilderness, were seen as removed from culture. In this way, the only persons who could be present there were defined as part of nature; only indigenous people with a subsistence relationship to nature, living off the land, could be seen as existing in this area (Turner, 1979).

Much of the historical development in traditional Arctic areas (a smaller selection of areas compared to those involved in current region-building processes) has relied on the descriptive logic inherent in notions of the frontier. Northern Canada, descriptions of which have dominated literature using the label "Arctic," has often been described in terms of the frontier, with the descriptions centering on the environment, indigenous peoples, and forms of subsistence (Keskitalo, 2004). Somewhat similar processes can be seen in portrayals of Alaska in relation to the mainland United States, Greenland in relation to Denmark, and to some extent, Russia (Keskitalo, 2004). However, frontierrelated terms have been rejected for mainland Norway, for instance, following most intensive debate in the 1980s (Brox, 1984; Aas, 1998). Sweden, Finland, and Iceland have historically not been discussed as Arctic areas, as this term has regularly focused on the states bordering the Arctic Ocean. These countries have thus not necessarily been subject to processes associated with the term "Arctic," and in Sweden, domestic research and discourse regularly use other terms. Discussions of regional "norths" exist in the area, but the language used exhibits none of the very strong and specific characteristics related to the term "Arctic."

Region-building in the case of an extended Arctic, one including areas not traditionally viewed as Arctic and in which development has been likened to the frontier or understood through frontier-related terms, may thus associate traditionally Arctic characteristics with areas to which they have not earlier been associated. Such a development has earlier been criticized as a process creating an "Arctic Orientalism," whereby already highly criticized descriptions focusing solely or mainly on environmental and indigenous (particularly subsistence-related) characteristics related to the frontier are selected, committing descriptive violence against the extended region (Keskitalo, 2004). In reviewing the ways in which a region is described and constructed, as well as what is included in it and what is not, it is thus crucial to understand the regional resistances or other existing discourses, descriptions, conditions, and development paths of the areas included. These understandings may indicate the limitations as well as the political and piecemeal nature of categorical regional descriptions created through region-building. As regional developments are inherently political, it is the responsibility of research to problematize and highlight the ways in which descriptive violence inherent in the process of region-building may manifest itself and the ways in which selected characteristics within discourse may not match the areas to which that discourse is applied.

\section{METHODS}

An Arctic Council ministerial declaration in 2002 called for a report that would constitute "a comprehensive knowledge base for the Arctic Council's Sustainable Development Programme" (AHDR, 2004:15). In response, the Arctic Human Development Report (AHDR) was developed during Iceland's chairmanship of the Council from 2002 to 2004. The report states its aim as seeking "to identify characteristics of human development that are informative in their own right and that can pave the way for collecting data that can be used in devising indicators that illuminate the special features of life in the Arctic" (AHDR, 2004:17). Attempting to relate its descriptions to the administrative regions that most closely reflect the Arctic Council's focus on including areas above the Arctic Circle, the report includes "all of Alaska, Canada North of $60^{\circ} \mathrm{N}$ together with northern Quebec and Labrador, all of Greenland, the Faroe Islands, and Iceland, and the northernmost counties of Norway, Sweden and Finland" as well as in Russia "Murmansk Oblast, the Nenets, Yamalo-Nenets, Taimyr, and Chukotka autonomous okrugs, Vorkuta City in the Komi Republic, Norilsk and Igsrka in Krasnoyarsky Kray, and those parts of the Sakha Republic whose boundaries lie closest to the Arctic Circle" (AHDR, 2004:17-18). The report has been rather influential, and publication of a second version is planned for 2014.

We review selected parts of the AHDR in order to compare the descriptions in the report for Sweden with domestic public data and reports available for the Swedish areas of Norrbotten and Västerbotten. The selection of characteristics targeted for comparison in the results is based on 


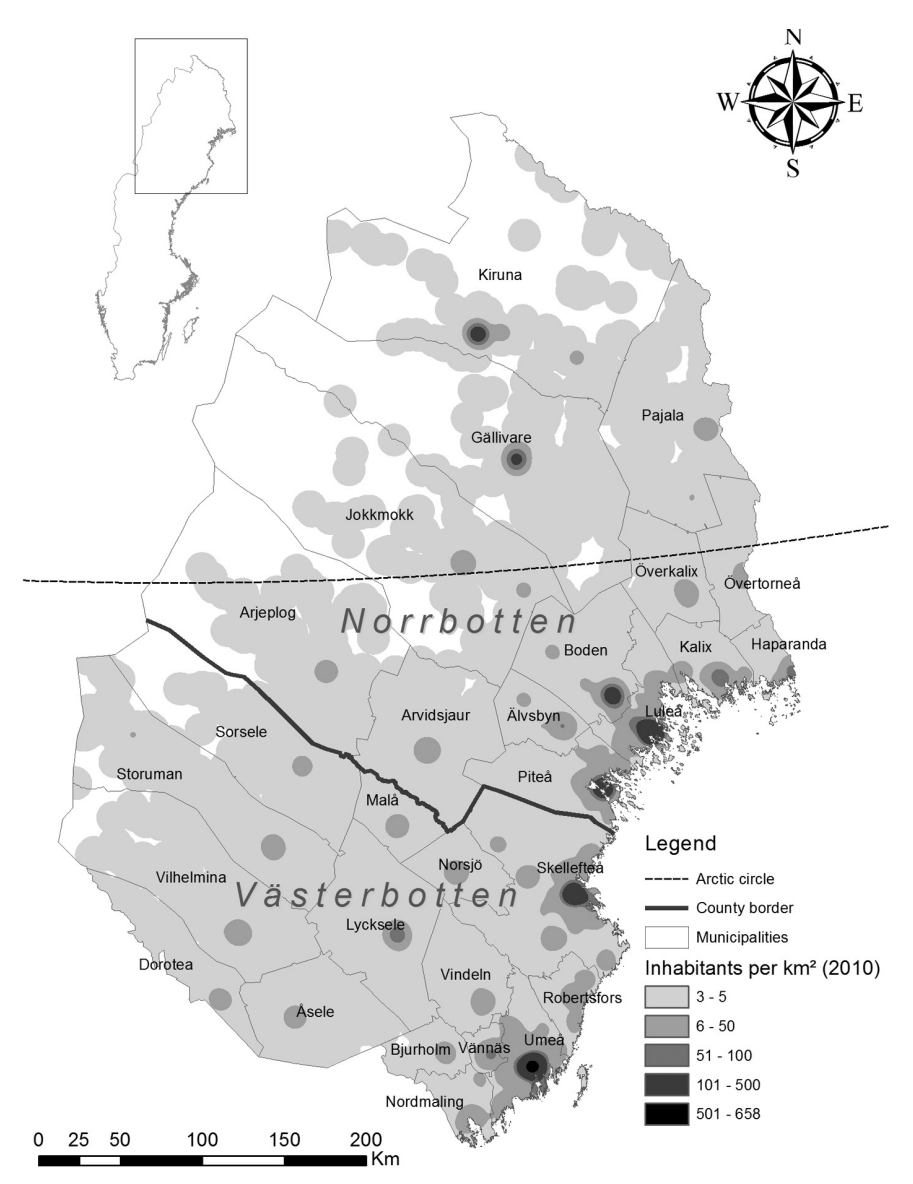

FIG. 1. Map of Västerbotten and Norrbotten, the two northernmost counties of Sweden, targeted in the analysis in this article. Map courtesy of Olof Olsson and Tommy Lind.

descriptions in the report (2004) of a) demographic factors, fertility, mortality, migration, age structure, and indigenous populations, and b) societies and cultures and economic and political systems, population groups and settlement patterns, including availability of information on these, types of change highlighted in descriptions of these regional structures, types of studies of population, and economic characteristics of the regions. We focus in particular on factors relevant to population and economic structure.

In the case of these factors, demographic, social and economic data are presented that draw upon official data from Statistics Sweden. Longitudinal, geo-referenced, microlevel data, arranged as a special register database that includes the entire population, comprise the basis for the population density map. Each resident in the area is mapped with $100 \mathrm{~m}$ accuracy, which provides a distinct visualization of geographic population distribution. In addition, the comparison draws upon published research into demography, as well as social, economic, and political systems, using both quantitative and qualitative methods referred to in the text. The sources in this paper have been selected to represent the published Swedish literature and internal descriptions of the areas and to explain the patterns identified in public statistical material. The published research represents internal Swedish discourses based on specific focal areas and development paths (rather than literature that includes this area in overviews of the "Arctic" related to the work of the Arctic Council). Sources thus include reports written in Swedish that represent Swedish internal descriptions. While our primary aim is to describe the present situation, just as the AHDR does, at some points we highlight development trends that contrast with the assumptions incorporated in and highlighted for the AHDR.

Norrbotten and Västerbotten have been chosen as the source of demographic and economic data for Sweden because the two counties are the largest area described in the AHDR as well as the area made relevant in much northern cooperation (see Fig. 1). We refer to the area as the "Swedish North." While the area is larger than the smallest area included in Arctic cooperation, the counties are not so dissimilar structurally as to make their inclusion irrelevant to the very broad descriptions and trends targeted in the report (differences, when existing, are described in the text). Including both Norrbotten and Västerbotten also makes it possible to compare the economic factors in AHDR that cover both counties and highlights development in two Swedish counties included in Barents Euro-Arctic region cooperation.

We begin with descriptions from the AHDR and then contrast them with descriptions from the domestic Swedish data. The relative brevity with which results in the AHDR are treated compared to domestic data reflects the space given to descriptions of Sweden in the AHDR.

\section{DEMOGRAPHY}

\section{Descriptions in the AHDR}

Under the heading "General population characteristics," the chapter on Arctic demography notes that "fertility, although decreasing, is generally higher in the Arctic when compared to southern parts of Arctic countries and the Nordic countries in Europe as a whole. Mortality is also higher, and life expectancy, accordingly, is lower" (AHDR, 2004:27). The chapter further notes a net loss of population due to migration and that the "age structure of the Arctic population differs from that of its more southern counterparts. The most noticeable difference is the relatively high share of the population in the labor-force age group, as well as in younger age groups in some circumpolar regions, and a smaller portion in older age groups." The section further notes that "in the countries where there are data for the indigenous populations, these populations tend to be much younger, with a very high share of their populations under 5 years old." The comparison places a particular focus on indigenous versus non-indigenous populations; however, a table notes that only about $5 \%$ of the population in northern Norway, Sweden, and Finland can be considered indigenous.

Organized in terms of general comparisons of the identified parts of the countries, the chapter goes on to note a number of ways in which Sweden actually differs from 
much of the "general population characteristics" identified above. For instance, "in both Norway and Sweden, the differences in fertility rates are small between the Arctic and the rest of the country" (AHDR, 2004:32) and, similarly, "Scandinavian countries... are among those countries whose life expectancy, on the whole, is among the highest in the world" (AHDR, 2004:33). It also notes, with reference to the general observation that Arctic areas have a "smaller share of those in older age groups," that "there are small though noticeable features making Sweden's Norrbotten and Finland's Lapland different from their corresponding country's national age structures. The share of younger adults $(25-39)$ is somewhat smaller here, while that of older adults $(40-59)$ is bigger than in the countries as a whole" (AHDR, 2004:36). In a similar vein, the report points out that "the differences in the tops of the pyramids are even more radical. The greatest shares of seniors are in Norrbotten and in Lapland, where they are even higher than in the total populations of Sweden [and] Finland. The smallest shares of seniors are in the Arctic regions of Canada and Greenland. Those few who are 70 years or older lived here during periods of high mortality, especially high infant mortality" (AHDR, 2004:37). The chapter also notes that "in Norrbotten (Sweden), unlike its Nordic neighbours, the migration outflow of population at times changes into an inflow" (AHDR, 2004:39). There is no clear description of the dominant problems of an aging population in these areas identified in domestic Swedish studies. The chapter concludes that "age structures ... are very much affected by the relative shares of non-indigenous and indigenous populations in a particular region" and that additional data would be needed to supplement the now "disjointed picture of the overall demography of the circumpolar region" (AHDR, 2004:40).

\section{Descriptions in Swedish Domestic Research}

As indicated in the AHDR, the general picture of Arctic demography does not apply very well to the Swedish North: the age structure is different, and mortality rates are on average lower compared to the rest of the Arctic; the population density is higher; and the indigenous population is a smaller share of the total. In many ways, the population structure corresponds more closely to conditions in the southern parts of the country, although the Swedish North does have its unique demographic structure, one more similar to patterns in other European peripheries, especially those in Finland and Norway. These differences and similarities have their roots in the historical development of settlements and population structure.

While Arctic areas are often seen as characterized by the presence of indigenous populations with a subsistence lifestyle (AHDR, 2004), the Sami in the Swedish context have long been a relatively small minority even in northern areas. The situation is similar in northern Finland and Norway as well. Populations are also strongly mixed: many residents in the Swedish North have a strong Sami identity, and many have Sami ancestors. As Statistics Sweden does not provide ethnicity as a category for classification, but only country of birth and citizenship, it is not possible to compare indigenous nations such as the Sami or Romany populations. In the case of the Sami, there are major economic, social, and cultural differences within the group depending on whether one is a member of a Sami community or has reindeer herding rights, for example, rather than being merely an ethnic Sami. There is no clear definition of who is a Sami in Sweden. For this reason, most statistics regarding the Sami population are relatively uncertain. The official figure is about 20000 Sami, of whom approximately 7000 are estimated to speak the Sami language (Ministry of Agriculture, 2009). Even though many Sami people still live in the northernmost counties, and especially in the municipalities close to the border with Norway (Fig. 1), it should be noted that the Sami population is nowadays spread throughout the country. In May 2009, the number of persons in Sweden registered as eligible to vote in elections to the Sami Parliament was 7809 . To be eligible, one must be at least 18 years of age, consider oneself a Sami, and fulfill at least one of the following criteria: 1) One has used the Sami language at home, or has parents or grandparents who have used Sami or 2) one has a parent who is or has been listed in the electoral rolls of the Sami Parliament. Further differences in demographic structure between the Sami and the non-Sami population seem to be quite small. For instance, various authors (Hassler, 2005; Sjölander, 2011) note that the Sami have a health situation and life expectancy similar to those of the national majority population. While presence of the indigenous Sami population is in itself an important feature of the Swedish North, the population structure and the demographic change in the region are influenced only to a marginal extent by any specific demographic features in the indigenous population.

Another difference from large parts of the Arctic, in particular Canada, Greenland, and Russia, can be seen in settlement structure. In large parts of the Arctic, settlements are small and rather isolated, and the population is small outside villages and small towns; settlements also include vast sparsely populated lands, sometimes without any settlements or economic activities. Moreover, many settlements are based on temporary resource exploitation and have a short life span (AHDR, 2004). In comparison, the Swedish North has a relatively dense population and a diversified system of population centres, comprising villages, small towns, and cities, based on a stable population of long-term residents. The counties of Västerbotten and Norrbotten together have a population density of 3.3 inhabitants per $\mathrm{km}^{2}$, compared to 0.026 for Greenland, 0.486 for Alaska, and 0.068 for Yukon Territory (see Table 1). It is mainly in the northern mountain range close to the border with Norway that we find very low population densities and very sparse settlement structures (Fig. 1). These areas are often seen as the last wilderness areas in Sweden. They host the major national parks and nature reserves, but they are also important lands for reindeer herding during spring, summer, and autumn. 
TABLE 1. Births, life expectancy, population density, age composition, and population change in the Swedish North, Sweden total, Greenland, Alaska, and Yukon.

\begin{tabular}{|c|c|c|c|c|c|c|}
\hline & $\begin{array}{l}\text { Births per } 1000 \\
\text { in the population }\end{array}$ & $\begin{array}{l}\text { Life expectancy (years): } \\
\text { Men, Women }\end{array}$ & $\begin{array}{l}\text { Population } \\
\text { per } \mathrm{km}^{2}\end{array}$ & $\begin{array}{l}\text { Percentage } \\
\text { over } 65\end{array}$ & $\begin{array}{l}\text { Percentage } \\
\text { below } 19\end{array}$ & $\begin{array}{c}\text { Annual population } \\
\text { change }\end{array}$ \\
\hline Swedish North ${ }^{1}$ & $10.0^{2}$ & $78.7,82.9(2006-10)$ & 3.3 & 19.7 & 19.9 & $-0.02 \%(2001-11)$ \\
\hline Sweden total ${ }^{1}$ & $11.5^{2}$ & $79.1,83.2(2006-10)$ & 22.9 & 18.0 & 21.6 & $+0.6 \%(2001-11)$ \\
\hline Greenland $^{3}$ & 14.5 & $66.6,71.6(2008)$ & 0.026 & 7.2 & 28.0 & $+0.001 \%(2003-12)$ \\
\hline Alaska & $16.7^{4}$ & $75.8,81.3(2010)^{5}$ & 0.486 & $7.7^{6}$ & $18.8^{6}$ & $+1.3 \%(2000-10)^{6}$ \\
\hline Yukon & $10.9^{7}$ & $74.0,77.7(2006)^{8}$ & 0.068 & $9.3^{8}$ & $20.3^{8}$ & $+1.6 \%(2002-11)^{8}$ \\
\hline
\end{tabular}

${ }^{1}$ Statistics Sweden (2012).

${ }^{2}$ Average annual number of birth per 1000 inhabitants 2002-10.

${ }^{3}$ Statistics Greenland (2012).

${ }^{4}$ State of Alaska (2010).

${ }^{5}$ State of Alaska (2007).

${ }^{6}$ State of Alaska (2012).

${ }^{7}$ Government of Yukon (2013).

${ }^{8}$ Government of Yukon (2012).

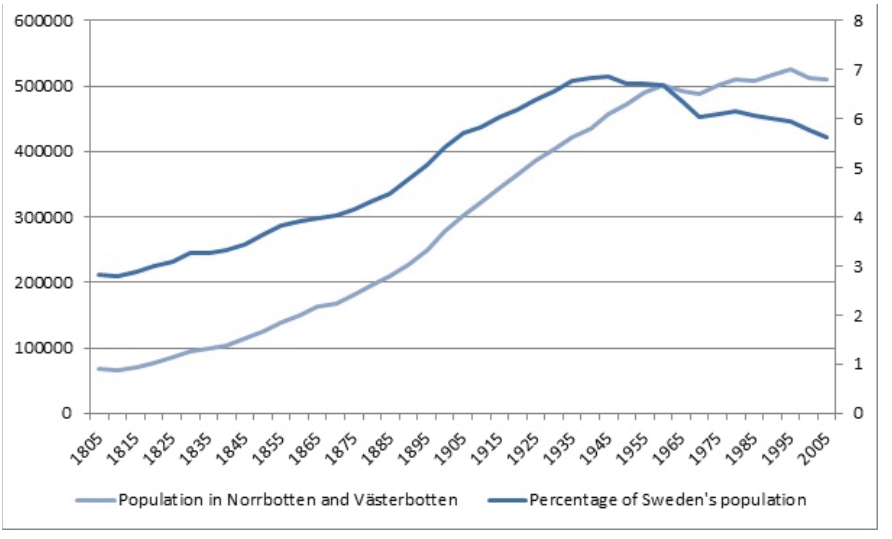

FIG. 2. Population development in Västerbotten and Norrbotten counties, 1805-2005. The grey line indicates population numbers and the black line the percentage of national population. Source: Statistics Sweden, 2012.

The population densities generally decrease when moving from the east to the west (i.e., away from the coastal areas) and from southern to northern areas within the Swedish North. This is one instance of contrasting patterns between Norrbotten and Västerbotten. As shown in Figure 1, the settlement pattern in the interior parts of Norrbotten is more concentrated than in the corresponding part of Västerbotten. In Västerbotten, the settlement structure is more spread out along rivers and lakes. The mountain range area bordering on Norway is also less populated in Norrbotten, except for the mining municipality Kiruna. This pattern has its roots in a long history of a settled agrarian population and also of urban settlements established several centuries ago. Though northern Sweden is located at high latitude, the North Atlantic Drift makes the climate relatively mild and has enabled the expansion of agriculture and forestry communities and a long-term trend of population growth over hundreds of years (see Table 1). Urban centres have emerged that were based on trade, administration, and later, industry and services. Population growth has taken place mainly along the coast of the Bothnian Sea, but in the late 18th century, through a policy of inland colonization, the population expanded along river valleys and farther into areas with potential for forestry and other natural resource-based activities (see e.g., Bylund, 1956).

As a consequence, the overall trend from approximately 1800 to 1950 was rapid population expansion (Fig. 2). More recently, in the second half of the 20th century, restructuring of agriculture and forestry resulted in net out-migration from the rural areas, population decline and aging population in large parts of the Swedish North, in particular in the more sparsely populated inland areas (e.g. Pettersson, 2001a, 2002, 2010). For many of the inland municipalities in the Swedish North, the population peak was reached in the 1950 s. However, compared to the national average, the rate of growth for the northern population had already started to decline during the 1930s. The Swedish North today has a smaller share of young people compared to the national average and certainly an older (and aging) population compared to the Arctic as a whole (Table 1).

Although large parts of the northern regions have experienced a population decline in recent decades, the population in the area overall has remained on a rather stable level, as the urban areas on the coast of the Bothnian Sea have attracted migrants from the region but also from other parts of Sweden and from other countries. A difference in national perspective, however, is the share of foreign-born persons, which is at present only $9 \%$ in Norrbotten and $8 \%$ in Västerbotten compared with 15\% for the whole of Sweden. As a result, efforts to attract migrants seem to have had only marginal effects on the in-migration rates, since counter-urban migrants tend to choose destinations closer to the urban areas in southern Sweden (Hjort and Malmberg, 2006). Although some earlier out-migrants return to the two northernmost counties, the number of returnees is still very small (Lundholm, 2012). As a consequence, the proportion of the Swedish population living in Norrbotten and Västerbotten has declined in recent decades. In 1970, these two counties accounted for $6.0 \%$ of the population; in 
2010, this figure had declined to 5.4\% (Statistics Sweden, 2012) (Fig. 2).

The age composition in more remote parts of northern Sweden, as in many peripheral areas, is strongly influenced by previous high out-migration of young people, which has resulted in an age structure with an increasingly aging population and thereby lower crude birth rates in the sparsely populated areas of the Swedish North. In several of the smaller municipalities, out-migration has been substantially higher for women than for men, which has influenced the sex composition and resulted in a debate about the consequences of male overrepresentation in the region. Yet for the region as a whole, the gender differences in migration rates are not very large. For the age group 15 to 35 , the female percentage of the population is 47.2 for the two northernmost counties, but 48.7 for the whole country (Statistics Sweden, 2012). The issue of female underrepresentation in the North seems to be a major one in the public debate, but is a rather marginal phenomenon in the population statistics, at least when looking at the situation in the regions as a whole. As a result of a rather high fertility rate and relatively high numbers of young people in the coastal centres, the number of children born per inhabitant is today quite similar to the average for Sweden as a whole (Table 1). In the Arctic comparison, the rates in the Swedish North are not substantially different from those found in Greenland, Alaska, and Yukon, despite the aging population in northern Sweden and in Sweden at large (Table 1.)

Mortality in the Swedish North is, as in the other Nordic parts of the region, different from the Arctic average in that the life expectancy is higher. In comparison to Alaska, the difference is rather small but the contrast to Greenland is very strong, with a life expectancy 12 years higher for men in the northern part of Sweden. For a long time the Swedish North has had higher crude mortality rates than the rest of the country because of its age structure and higher agespecific mortality rates. At present, the trends favour the northern regions, and any differences in life expectancy from the national average are marginal (Table 1).

When analyzing the population structure of the Swedish North, it is important to stress the heterogeneity of the region, which spans remote and sparsely populated areas located in the inland and mountain areas as well as dynamic cities along the coast of the Gulf of Bothnia. Although in the national context the Swedish North has often been identified as a remote, sparsely populated periphery (e.g., Eriksson, 2010), in comparison to the Arctic in general it is a densely populated area. One feature of particular interest is that it features two major urban areas, which indicates urbanizing trends over time. According to figures from Statistics Sweden, 37\% of the northern population today resides in the two municipalities of Umeå (Västerbotten) and Luleå (Norrbotten) and 33\% in the other coastal municipalities, while the population in the inland municipalities has decreased over the last decades from about $40 \%$ of the regional population in 1970 to approximately $30 \%$ today (Statistics Sweden, 2013). Luleå and Umeå have large and relatively high-ranked universities, with 16000 and 37000 students, respectively, as well as an expanding local labour market based mainly on the service sector.

While the Swedish North in its national context has been identified as a place of relative population decline and limitations in economic development (e.g., Wiberg, 2000; Wiberg et al., 2002; Eriksson, 2010), the picture is somewhat different in an Arctic context. In fact, the decline in population is still quite slow despite limited employment opportunities and prospects for young people to remain in some (especially inland) areas. One reason could be the strong attachment to the place of residence, visible for instance in a resistance among people over age 30 to migrate from the region. In general, people have a high degree of attachment to their place of residence, as well as to the municipality and region in which they live, and this applies to residents in the Swedish North (Westin, 2012). Many families have lived in specific areas for generations, and people have established local social networks and local insider advantages that are not transferable to other contexts (Fischer and Malmberg, 2001). Even though unemployment is a structural problem within the sparsely populated areas of the region, not least among young adults, many tend to stay simply because they want to. For those who stay, their attachment to the locality increases and migration becomes less attractive or likely (Westin, 2012). The combination of a public sector providing jobs and a general welfare system also makes it possible for people to remain although the labour market is far from being as dynamic as it is in the metropolitan areas and larger cities. Overall, then, a rather dense and stable population is a key feature of the Swedish North in comparison with (other) Arctic areas.

\section{SOCIETIES AND CULTURES, AND ECONOMIC AND POLITICAL SYSTEMS}

\section{Descriptions in the Arctic Human Development Report}

The report chapter titled "Societies and Cultures: Change and Persistence" notes a number of general descriptions of the Arctic. The chapter identifies three groups that can be said to make up the Arctic population: indigenous people, more recent settlers (and mixings between these two groups), and recent immigrants born outside the region (AHDR, 2004). Further, it is said that the report will devote more attention to:

indigenous societies and cultures than to later immigrants. There are two main reasons for this. One is that, except in Europe, the literature describing social and cultural processes in the Arctic from a local perspective has focused on indigenous communities. Although more recent settlers figure prominently in national statistics, qualitative data about their communities are rare. For groups of mixed cultural ancestry, as well as for recent immigrants, data are even 
less readily available. The other reason is that rapid social and cultural change has affected small-scale indigenous societies much more heavily than other groups. (AHDR, 2004:46)

The chapter also recognizes a dominance of studies in anthropology and notes that "while this has led to a number of excellent studies on the local level, regional and national data are much rarer" (AHDR, 2004:64).

The chapter titled "Economic Systems" includes data on Norrbotten and Västerbotten as "political and administrative entities overlapping the Arctic for which relevant sets of data are publicly available" (AHDR, 2004:69). The chapter reports that characteristics that set the Arctic apart from other regions are the large role of large-scale resource exploitation; the large role of "family-based commercial fishing or customary hunting, fishing, breeding and gathering activities"; and the role of transfer payments from regional and national governments to support consumption and public services (AHDR, 2004:69). The chapter only briefly notes that Sweden, together with Norway, Finland, and Iceland, is relatively densely populated compared with other areas in the Arctic (three-quarters of the population of the Arctic outside Russia). These areas also have a number of common characteristics, including "remarkably advanced" communication and transportation systems, public services, and tertiary sectors (AHDR, 2004:76), as well as relatively high economic diversification and a large contribution to the economy. The report also states that these areas together make up one-fifth of the Arctic economy.

In addition, although fishing is recognized as being of considerable importance, the chapter does not include descriptions of the importance of forestry, a shortcoming in comparison with other Arctic Council-related work (e.g., ACIA, 2005). It is also inconclusive on salary levels in these areas of northern Sweden in comparison with the country as a whole (AHDR, 2004:78).

Despite this acknowledgement of the role of the public sector and administration in Sweden, Norway, Finland, and Iceland, the chapter entitled "Political Systems" focuses on "the development of indigenous influence in the political systems of the Arctic" (AHDR, 2004:85). This emphasis means that the role of municipal and regional government in relation to the state, which affects the distribution of authority to the local level, is omitted.

\section{Descriptions in Swedish Domestic Research}

Given the definitions and selection of material above, the AHDR does not recognise the long periods during which different peoples in northern Europe have mixed and cohabited and which have resulted in many distinct population groups and very long residence periods for a number of groups and communities. The report also does not make use of the abundant data on societies in northern Sweden. Much of the data on the population in general in the Swedish
North does not use the label "Arctic" (as this is not a regular domestic identifier), but rather discusses the Swedish North in terms of either specific counties or any selection of the country's five northernmost counties. An abundance of literature exists on regional development in specific cities, towns, and small communities, and rural and town histories for these different configurations of counties. In addition, one can find significant statistical material for the northernmost counties in quantities certainly no smaller than material available for more southern areas. Given the relatively large-scale nature of habitation in northern Sweden compared with many other areas of the Arctic (discussed in the previous section), anthropology has, however, not been the discipline of choice, as it were, for describing community life in northern Sweden. Instead, the focus has been on studies of the development of manufacturing, forestry, mining, private and public services, and tourism and on urbanization and rural development, all of which fall under disciplines such as geography and economics (see e.g., Pettersson, 2002; Lundmark, 2006; Westin, 2006; Ejdemo and Söderholm, 2011).

The large-scale colonization of the western parts of northern Sweden started in the 17th century and went on into the 19th century, a period much earlier than that in which corresponding developments occurred in areas included as Arctic and, in particular, in New World, frontier countries such as Canada (established as a confederation in 1867). It should thus be noted that for any application in Sweden, the group "recent settlers" described in the AHDR would include the children of migrants arriving in the 17 th and 18 th centuries. One motive for the colonization was the government's ambition to ensure that the territory was considered part of the state. Another, partly overlapping and very important reason was that the land contained important minerals, such as silver, copper, gold, and iron ore. To attract new settlers, the state introduced the "Lappmarksplakat" (Lapland protocol) as far back as 1673, which ensured that anyone who settled in Lapland would be exempt from taxes and conscription for war for 15 years (Arell, 1979; Norstedt, 2011). New farmsteads were established by Swedes who needed land and a way to support themselves, often on land already used by seminomadic Sami populations (and to a lesser extent by nonSami hunters). The land claims of the semi-nomadic Sami were not recognized by the state. Some Sami started farmsteads themselves, for instance, in order to establish rights to lands that otherwise ran the risk of being taken over by settlers colonizing the area. Marriages between Swedish settlers and Sami were quite frequent, giving rise to a mixed population with long ancestries in the region (Arell, 1979). In addition, after the war between Russia and Sweden in 1808-09, Sweden lost Finland, and while the western part of the Torne River valley dividing Sweden and Finland remained in Sweden, the eastern part became part of the Russian Empire. This meant that the Finnishspeaking population on both sides of the Torne River was suddenly divided between two countries. The Swedish 
municipalities close to the Finnish border still have a Finnish-speaking population, with their dialect usually referred to as "Meänkieli." Like the Sami language, Meänkieli was targeted for assimilation into the Swedish population and majority language, presumably as part of a nation-building movement. In the year 2000, Meänkieli was acknowledged as one of Sweden's minority languages, raising the status of the language (Elenius, 2008). In recent years, the interest in collaboration between Swedish and Finnish municipalities in this region has increased substantially, stimulated in particular by the common language and the accession of both countries to the European Union in 1995 (Mattsson and Pettersson, 2005; see also Waara, 1996; Jacobsson and Waara, 2008; Rantakyrö, 2008; Gloersen et al., 2009 for general descriptions of the area).

This analysis reveals that the population in northern Sweden is relatively more complex than the AHDR would suggest, as are its employment patterns and development over time. From the start of settlement in the $1600 \mathrm{~s}$, the farmers settling in the region in general gained ownership to large forest areas (used for fuel, construction, tools, and hunting, but also for summer pastures), although farmland was valued higher than forestland. As the demand for forest products increased in the late 19th century, farmers found a new source of income in selling timber and pulpwood to the expanding forest processing industries. Today farming is a minor industry in the Swedish North: in the period 1996-2007, the number of farms in the region decreased by $37 \%$, while the decrease in the rest of Sweden was considerably lower at 21\% (Statistics Sweden, 2012). However, the structure in which farms include large forest areas still remains, and this structure has given rise to a large body of private forest owners with historical ties to the area. Today, $8.5 \%$ of the inhabitants in the two northernmost counties are forest owners, compared to $3.4 \%$ for the country as a whole (Skogsstyrelsen, 2012). Forest ownership often provides income and a source of identification, even though today, as a consequence of urbanization, owners may work outside the holding in larger regional centres, and their main income may come from other employment. Although forest ownership and tradition often result in forests being used for fuel in second homes on the holdings or for hunting, ownership is increasingly being appreciated for its social and ecological values (Nordlund and Westin, 2011). Indeed, the right to hunt birds, small game, and moose is important as a personal hobby and resource, and today, also as a means for tourism companies to attract business.

One important point to note here in comparison to the focus in the AHDR (2004) is that hunting or fishing in these kinds of populations is not, as a rule, a form of subsistence, but rather part of a livelihood or a hobby related primarily to identity. Different population groups are also integrated into the overall settlement structure, with little differentiation between Sami or other local groups on the basis of habitation (Keskitalo, 2008).

Reindeer husbandry, practiced on more than a third of the Swedish area, is today also integrated into the market economy with the main income from reindeer husbandry being meat sales. Reindeer husbandry is also relatively modernized and may for instance use trailer trucks for moving reindeer, helicopters for monitoring a herd under difficult conditions, and pellets for additional feeding. It is a very small sector, with about 2500 persons officially making their living from the livelihood (Keskitalo, 2008; Ministry of Agriculture, 2009; Ministry for Rural Affairs, 2013). According to data from Statistics Sweden, in recent years about 500-540 persons have been employed in reindeer husbandry. Of these, roughly $70 \%$ are found in Norrbotten county and $15 \%$ in Västerbotten county. Being a small sector yet practiced across large areas, with well-established infrastructure, reindeer herding as an economic activity faces many challenges, such as conflicts over land use interests with forestry, mining, hydroelectric power, physical infrastructure projects, and the like. In recent years, windmill parks have added to the impacts encroaching on reindeer husbandry in northern Sweden. Environmental and climate change that may affect seasonal shifts, migration, and grazing may also give rise to uncertainties about the future of reindeer herding (Keskitalo, 2008). There are indications that this situation of increasing fragmentation and multi-use conflicts contributes to problems among reindeer herders with anxiety, depression, and limited hope for the future (Kaiser et al., 2010). However, such consequences may not be related primarily to overall living conditions in the areas, nor are they necessarily best explained through reference to cultural change (highlighted in overall descriptions in the AHDR, 2004). Rather, the difficulties in reindeer husbandry could be attributed to its requirement for extensive areas of land, land that increasingly is wanted for other uses, placing reindeer herders in conflict with much larger and economically stronger sectors (Pettersson, 2004; Keskitalo, 2008). Sami tourism has to some extent been launched as an alternative or at least complementary way of making a living based on Sami culture and traditions, just as tourism has been suggested as an option for diversifying the economic base in sparsely populated areas (Pettersson, 2004).

Thus, the area features multiple, generally marketintegrated livelihoods, as well as traditional practices, today often undertaken in the form of recreation. With regard to economic structure, the regions are going through changes as the predominantly industry-based employment structure of the mid-1900s is moving farther toward service provision and even toward being a post-productive countryside, that is, an area where recreation in second homes-once family homes - and tourism figure prominently in the local rural experience. This change is taking place as result of the structural transformation, for example that seen in forestry, in which labour in previously labour-intensive sectors is replaced by technology. However, while the role of local employment has diminished, the role of the forestry sector in GDP and exports has not diminished: quite the contrary (Pettersson, 2002; Lundmark, 2006). The structural change in the North started around the middle of the 20th century 
after a long period of relatively strong economic growth (and related population growth) based largely on the extraction and refinement of natural resources (Westin, 2006).

Thus, while employment in both extractive and renewable industries declined substantially in the 1960 s, jobs in manufacturing and the public and private service sectors have expanded. This development process and related restructuring, which occurred throughout Sweden but somewhat later in the northernmost counties, has led to a more fragmented socio-economic pattern than that which prevailed earlier. The general pattern is a concentration of employment options in the more densely populated areas and urban centres, mainly those along the coast of the Gulf of Bothnia, while the small inland municipalities have experienced a significant decrease in local employment (Pettersson, 2002; Lundmark, 2006). New options for rationalization of production, in combination with increased demand for labour in industries with higher productivity and in areas with more diverse job opportunities for both men and women, have contributed to out-migration and urbanization. There are some exceptions to this general pattern. In particular, some villages in the mountain range close to the border with Norway have had a much more positive development compared to many other inland areas. In these places, cross-border movement has contributed to new work opportunities, services, and stable or even increasing population numbers (Pettersson, 2001a, b). Especially villages with direct roads to Norway have expanded in recent years because of tourism, second-home development, and cross-border shopping.

As indicated in Figure 3, the public sector in the counties of Norrbotten and Västerbotten, which comprises public administration and the lion's share of education and health care, employs approximately $40 \%$ of the labour force, and the manufacturing sector $12 \%$. Employment in the public sector is much in line with that in Sweden as a whole and is part of a nation-wide high ambition to deliver services of a basic standard independently of local conditions. The general political structure is also significant in much of northern development, with the democratic system locally resting upon the municipality as an important focus of local planning. The Swedish local planning monopoly entails the municipality's right to plan land use and local development in detail, so much so that the municipality even has the right to veto developments such as nuclear or wind power. The economic strength of the municipalities to provide various types of services is to a large extent equalized across the country through a national transfer system between municipalities with a strong socio-economic structure and those with limited financial capacity. In this respect, one sees a significant dividing line between expanding urban centres and declining small municipalities. A great variety of measures have been implemented over the years to handle the consequences of this divergence within the framework of national and regional policy, and since 1995, European Union policy as well. During the last 40 years, options for training and education have increased significantly in these

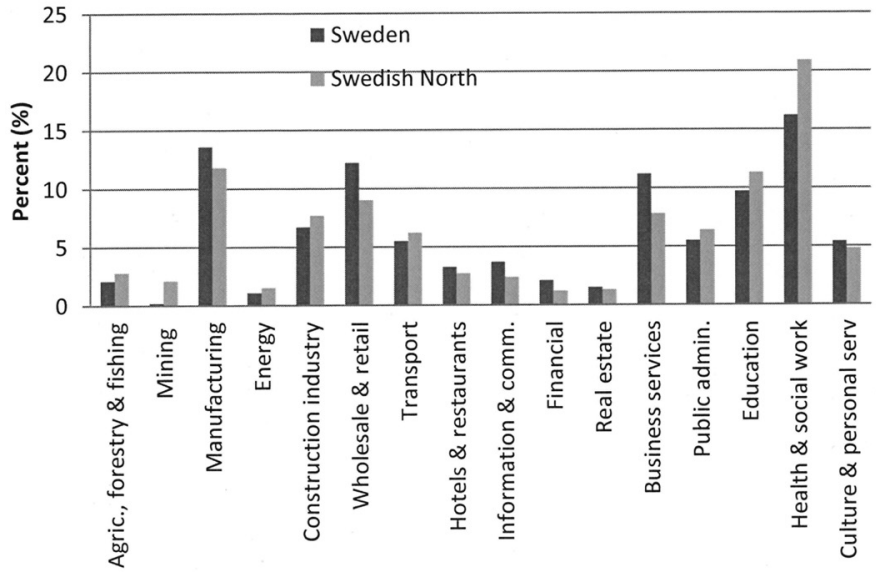

FIG. 3. Employment distribution (\%) by sector, 2010. Source: Statistics Sweden, 2013.

areas. Particularly noteworthy in this regard are efforts to develop competence and know-how through the establishment and development of university campuses in all main centres of the five northernmost counties (Wiberg, 2000).

An increasingly urgent challenge for many of the northern inland municipalities is to maintain their rather high level of various types of welfare services and physical infrastructure, which has been built up over recent decades but may be threatened as depopulation and an aging population lead to rapidly increasing per capita costs for the municipality. However, such processes cannot be dissociated from general changes towards hollowing-out of the state in Western societies or transformation of the welfare state (Giddens, 1998) and are largely dependent on political considerations. The classic form of welfare state governance manifested in Sweden, characterized by a strong public sector and distinct divisions of obligations between administrative levels and policy sectors, may here be challenged by limitation of services, particularly in sparsely populated rural localities. Such limitations may increase accessibility problems, leaving individuals and households more vulnerable and increasing their feelings of dissatisfaction and insecurity, especially as regards the need for reliable health care in cases of emergency (e.g., noted in recent cases in Wiberg, 2012; Wiberg and Lind, 2012). Such changes could also reduce the power of the countryside to attract lifestyle settlement and new employment opportunities, for instance through immigration from countries such as the Netherlands or Germany, which have been targeted to this end by northern municipalities.

On balance, the expansion of the public sector in the late 1960 s to some extent indicates a shift towards a postproduction economy with public and private services being dominating sectors. This overall pattern of employment in the labour market, similar throughout the North, differs mainly in the following respects from that of Sweden in general. As indicated in Figure 3, employment in the primary sector, albeit small in numbers, is in general greater in the Swedish North. The relative economic importance of 
the primary sector in the North-in particular mining, but also energy production and forestry-figures prominently when examining the gross regional product (GRP). Sweden, in particular northernmost Sweden, is among the dominating actors in Europe with regard to mining. In 2008, mining accounted for $8.6 \%$ of the GRP in the two northern counties, which can be compared to $0.6 \%$ of the total GNP for Sweden (Fig. 4). Given that the mining sector is expanding, its value is most likely to have increased since that date. In relation to this employment and economic structure, wholesale, retail, and business services employ a smaller share of the labour force in the two northern counties than in the rest of the country. Partly as a consequence of the aging population in the North, and partly as a result of the difficulties in organizing services efficiently in sparsely populated municipalities while aiming to maintain them to a particular standard, employment in the health and social sector is relatively larger in the North (Fig. 3). It can also be noted that while employment is high and the GRP is low in the public sector (on a regional as well as on a national level) (Fig. 4), this sector yields a high income to those employed in the areas. The public sector accounts for a larger share of the total income in the North than in Sweden as a whole: $55 \%$ in the two northern counties as against $46 \%$ in Sweden on average (Ekonomifakta, 2011).

With regard to development in these sectors, mining is recently experiencing a revival, with the discovery of additional ore deposits - primarily iron and copper - in many areas in Norrbotten and of complex ores containing zinc, copper, lead, gold, and silver in an area from the city of Skellefteå towards the interior of Västerbotten (the Skellefte district). The discovery of sulphide ores (not least those containing gold) has led to the opening of new mines and quarries in the interior of Västerbotten (the so-called Gold Line). The long-term trend of decreasing employment in mining changed into growth during the first decade of the 21st century. Changes in mining regulations in 1992 that opened up the country to more foreign investment, combined with a growing demand and rising prices for metals, have given rise to intense exploration activities and investment geared to opening up new mines and increasing production capacity in old ones (Knobblock and Pettersson, 2010). It is estimated that the mining company LKAB, which already manages, among other complexes, Europe's largest iron ore mine, in Kiruna, and has used mainly local employment throughout the 20th century, will need to recruit 1200 people in the coming five years (Nordnytt Television News, 26 September 2011). Estimates indicate a multiplier effect of between 1.5 and 2.5 and generally around 2 in the area (Malmfälten) (Anderstig, 2011). This would mean that 1200 new jobs in mining would yield in total 2400 jobs, which is a significant increase in a local labour market that has approximately 20400 employed people today. During 2012 a new large-scale iron ore mining operation is being started up in the small Norrbotten municipality of Pajala, located on the Finnish border, a relatively sparsely populated area where the expansion of

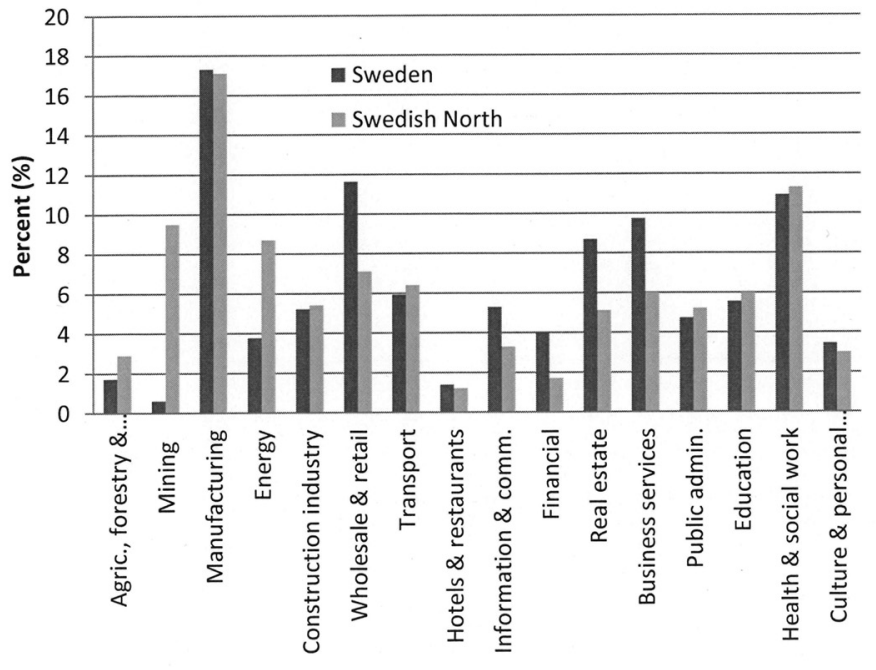

FIG. 4. Distribution of gross regional product (\%) in Sweden and the two northernmost counties in 2010. Source: Statistics Sweden, 2013.

employment will have even more dramatic consequences. At present, the number of local residents employed in Pajala municipality is approximately 2500 , and plans are to recruit at least 1000 persons within the next five years. With a multiplier estimate corresponding to that for Malmfälten, the relative increase in number of jobs will be at least $65 \%$ (cf. Ejdemo and Söderholm, 2011).

In addition to mining, the energy sector, with $1.4 \%$ of the employment, contributes $8.4 \%$ of the GRP. The sector comprises primarily hydropower production. The demand for labour is low, as the construction phase is more or less over, and management and monitoring require few workers. In recent years, the interest in wind power and bio energy has increased substantially. New windmill parks have been established, and there are plans for many more in the forthcoming years. The largest and by far the most spectacular project is to build a major windmill park in the inland areas west of Piteå (southern Norrbotten), which would include about 1000 turbines producing roughly $8-12 \mathrm{TWh}$ (Svevind, 2012). As with hydropower, it could be expected that the main effects on employment will be realized during the years while the windmill parks are being constructed.

As a final point with regard to economic structure, both the Swedish Arctic policy document (Swedish Department of Foreign Affairs, 2011) and the AHDR (2004) specifically mention tourism as a field of concern and possibilities. The AHDR highlights opportunities related to ecotourism, though the concept is not defined properly. Here, too, differences in development and scale of economic development can be noted. While small-scale tourism is present in many development policies and programs in the Swedish North, the reality differs considerably and mainly reflects the success of larger-scale units of tourism infrastructure. Müller (2011) has shown that many municipalities have in fact experienced decreasing numbers of overnight stays, caused mainly by decreasing domestic interest, and that only in a few locations can this loss be compensated for by 
increased international demand. Three destinations explain most of the positive development. First, since its establishment, the Ice Hotel outside Kiruna has developed into an iconic must-see attraction for tourists from all over the world, although often for a one- or two-night stay only. Second, the global car industry uses the sparsely populated area around Arvidsjaur as a locale for testing equipment under winter conditions. This enterprise attracts thousands of business travelers to the areas annually. Finally, the ski resort of Tärnaby/Hemavan, located in the northwestern part of Storuman municipality, has experienced a rejuvenation-not least as a budget resort for Norwegian tourists - which has turned the villages into lifestyle mountain communities able to attract younger in-migrants (Müller, 2006).

None of these developments can be characterized as small-scale tourism, however. Instead it has been shown that small-scale tourism development seldom can contribute to a successful restructuring of northern economies (Lundmark, 2006). Problems related to seasonality, limited demand, establishment of tourism businesses, and low revenues have thus far hindered such development. Moreover, smooth transport solutions - all the locations mentioned have airports and good road infrastructure - appear to be a crucial condition for success. While declining job opportunities in other sectors have made tourism a major industry in most communities, it is not an industry that can be relied upon to produce a fundamental change in the economic structure of the region (Müller and Ulrich, 2007).

\section{DISCUSSION AND CONCLUSION}

While one report such as the AHDR (2004), to a large extent developed under time pressure during the Icelandic chairmanship of the Arctic Council in 2002-04, cannot fully cover the specific situations of all eight Arctic countries, it is necessary to challenge the picture it presents and to refrain from drawing sweeping conclusions on similarities between the diverse countries based on the report's necessarily limited research into established domestic literature. While descriptions in the report on Sweden in particular are very limited, the selection of data (for instance, the focus on anthropological data) results in an incorrect description of conditions in all of the regions now described as Arctic. In particular, it is necessary to nuance the image with regard to areas that, despite being four out of eight countries and constituting three quarters of the population of the Arctic outside Russia (Sweden, Norway, Finland, and Iceland, according to the AHDR, 2004:76), are often less described than merely included in reviews of Arctic countries. It is essential to understand how these countrieswith their advanced communication and transportation, public services, and tertiary sectors, relatively high economic diversification, and large economic contributionsare constituted and based in national policy, population, and economic structures. Indeed, only in this way can one understand the Arctic region beyond historical and limited descriptions under the Arctic label and avoid misdescribing and fictionalizing the region (Keskitalo, 2004).

This study has reviewed public data and reports that are broadly relevant to the trends described in selected chapters in the AHDR. It should be noted, however, that the study does not claim that including the two northernmost counties of Sweden, discussed here, would produce a representation of the Arctic in Sweden that is any more accurate; rather, the study attempts to show that differences exist for any selection of Arctic area that could be made in Sweden. It shows that viewing the population and economic structure in particular, many of the assumptions in the AHDR that centre on relatively direct comparability of the eight Arctic regions instead reveal substantial differences between areas, with the northern Swedish regions strongly standing out from such a collapsed, simplified image. Instead of very small, younger, and rapidly growing (high birth rate) populations, the Swedish North is characterized by relatively dense habitation structures with a stable long-term resident and aging population and a very small and relatively integrated indigenous population that has largely the same health situation as the population overall. While depopulation and urbanization are evident, migration is partly directed at the larger regional centres, following a similar urbanization pattern in the Western world at large. Largescale infrastructure including renewable and non-renewable industry exists, although the service industry dominates today, including large-scale tourism facilities. Moreover, the situation in Sweden cannot be described in the simplified terms of the "transfer" economy discussed in the AHDR (2004). Instead, it is important to recognize that the limitations in diversification and scale, seen together with Western trends towards urbanization, result in problem complexes for already relatively sparsely populated regions. These may constitute a more common problem area across the Arctic than some descriptions suggest.

In illustrating specific situations in the northernmost counties of Sweden and comparing them to the corresponding descriptions in the AHDR, the paper has sought to contribute to a more nuanced image of northern areas. The hope here is that this will provide food for thought with regard to both Sweden's recent development of an official Arctic strategy and the next Arctic Human Development Report and will indicate the large variety between countries that needs to be taken into account in reviewing the Arctic as a region. Any development or any future AHDR that aims at truly describing the greatly varying areas making up the so-called region must acknowledge this variety, as well as the dubiousness inherent in promulgating terms associated with Arctic discourse in order to create a focus on certain characteristics. Any future AHDR or other reports that relate to the "Arctic" label must critically examine and review the mechanisms by which they include or exclude certain characteristics, examples being focusing on indigenous decision-making systems to the exclusion of the municipal or other decision-making systems 
that influence all groups in the areas. Similarly, any such report or descriptive measures must take care not to select only authors using the Arctic label; rather, descriptions that aim at truly taking into account all areas in the region must focus on internal accounts, which are marginalized by Arctic discourse and its associated political processes. In short, researchers must avoid taking the area of their research as a given and instead problematize it if they are to avoid the descriptive violence inherent in Arctic frontier discourse.

The Swedish situation indicates some areas that may fruitfully contribute to issues that are important to discuss for all northern areas, including relatively sparse population and low diversification (even in areas seen as being more diversified). Problems of scale when it comes to attracting and maintaining diversified employment in the face of urbanization may constitute one relevant avenue of inquiry, in which a proper understanding of the issues would be facilitated by strong and well-supported analyses embracing multiple regions.

\section{ACKNOWLEDGEMENTS}

The researchers gratefully acknowledge funding from the Mistra Arctic Futures program and the Department of Geography and Economic History, Umeå University. This research also constitutes a contribution to the recently established Arctic Research Centre at Umeå University (ARCUM).

\section{REFERENCES}

Aalbu, H., and Wiberg, U. 1997. How may institutional regionalization promote regional development. In: Dellenbrant, J.Å., and Wiberg, U., eds. Euro-Arctic curtains. Umeå, Sweden: Cerum Northern Studies, Umeå University. 77-101.

Aas, S. 1998. North Norway - the frontier of the North? Acta Borealia 15(1):27-41.

ACIA (Arctic Climate Impact Assessment). 2005. Arctic climate impact assessment: Scientific report. Cambridge: Cambridge University Press. 1042 p.

AHDR (Arctic Human Development Report). 2004. Akureyri, Iceland: Stefansson Arctic Institute.

AMAP (Arctic Monitoring and Assessment Programme). 1998. AMAP Assessment Report: Arctic pollution issues. Oslo: AMAP.

Anderson, B. 1991. Imagined communities: Reflections on the origin and spread of nationalism. London and New York: Verso.

Anderstig, C. 2011. Regionala effekter av nya gruvor i Norroch Västerbotten - en kommentar [Regional effects of new mines in Norrbotten and Västerbotten - a commentary]. WSP Consulting.

Arell, N. 1979. Kolonisationen av lappmarken: Några näringsgeografiska aspekter [The colonization of Swedish Lapland: Some economic-geographical perspectives]. Lund: Berlings.
Brox, O. 1984. Nord-norge fra allmenning til koloni [Northern Norway from common to colonial]. Oslo: Universitetsforlaget.

Bylund, E. 1956. Koloniseringen av Piteå lappmark t.o.m. 1867 [The colonization of the Piteå Lapland areas until 1867]. Geographica nr 30. Uppsala: Uppsala Universitet.

Crawford, A., Hanson, A.J., and Runnalls, D. 2008. Arctic sovereignty and security in a climate-changing world. Winnipeg, Manitoba: International Institute for Sustainable Development.

EC (European Commission). 2008. Communication from the Commission to the European Parliament and the Council: The European Union and the Arctic Region. COM (2008) 763 final. Brussels: European Commission.

Ejdemo, T., and Söderholm, P. 2011. Mining investment and regional development: A scenario-based assessment for northern Sweden. Resources Policy 36(1):14-21.

Ekonomifakta. 2011. Regional statistik [regional statistics]. http:// www.ekonomifakta.se/sv/Fakta/Regional-statistik/Alla-lan/ Vasterbottens-lan/?var=2651.

Elenius, L. 2008. Transnational history and language barriers: A baseline study of socio-economic effects of Northland Resources ore establishment in northern Sweden and Finland. Luleå: Luleå University of Technology.

Eriksson, M. 2010. (Re)producing a periphery: Popular representations of the Swedish North. PhD thesis, Department of Social and Economic Geography, Umeå University.

Fischer, P.A., and Malmberg, G. 2001. Settled people don't move: On life course and (im-) mobility in Sweden. International Journal of Population Geography 7(5):357-371.

Foucault, M. 1974. The archeology of knowledge. Translated from the French by A.M. Sheridan Smith. London: Tavistock Publications.

Giddens, A. 1998. The third way: The renewal of social democracy. Cambridge: Polity Press.

Gløersen, E., Dubois, A., Roto, J., Rasmussen, R.O., and Sterling, J. 2009. Development perspectives for the NSPA: Opportunities and challenges. Nordregio Working Paper 2009:5. Stockholm: Nordregio.

Government of Yukon. 2012. Population report: March 2012. Information sheet 58.39. Whitehorse: Yukon Bureau of Statistics.

. 2013. General facts: Vital statistics. Whitehorse: Yukon Executive Council Office. http://www.eco.gov.yk.ca/stats/1467. html\#Vital.

Granholm, N., and Kiesow I. 2010. Olja och gas i ett nytt och förändrat Arktis: Energifrågans utveckling mot bakgrund av regionens strategiska dynamik [Oil and gas in a new and changing Arctic: Energy development of the issue in light of the region's strategic dynamics]. Stockholm: Swedish Research Agency FOI.

Hassler, S. 2005. The health condition in the Sami population of Sweden, 1961-2002: Causes of death and incidences of cancer and cardiovascular diseases. PhD thesis, Faculty of Medicine, Umeå University.

Hjort, S., and Malmberg, G. 2006. The attraction of the rural: Characteristics of rural migrants in Sweden. Scottish Geographical Journal 122(1):55-75. 
Jakobsson, M., and Waara, P. 2008. Demography and social conditions in Pajala and Kolari. Luleå: Department of Human Work Sciences, Luleå University of Technology.

Jansson, D.R. 2003. Internal orientalism in America: W.J. Cash's The Mind of the South and the spatial construction of American national identity. Political Geography 22(3):293-316.

Kaiser, N., Sjölander, P., Edin Liljegren, A., Jacobsson, L., and Salander Renberg, E. 2010. Depression and anxiety in the reindeer-herding Sami population of Sweden. International Journal of Circumpolar Health 69(4):383-393.

Keskitalo, E.C.H. 2004. Negotiating the Arctic: The construction of an international region. London: Routledge.

2008. Climate change and globalization in the Arctic: An integrated approach to vulnerability assessment. London: Earthscan.

Knobblock, E., and Pettersson, Ö. 2010. Restructuring and riskreduction in mining: Employment implications for northern Sweden. Fennia 188(1):61-75.

Lundholm, E. 2012. Returning home? Migration to birthplace among migrants after age 55. Population, Space and Place 18(1):74-84.

Lundmark, L. 2006. Restructuring and employment change in sparsely populated areas: Examples from northern Sweden and Finland. PhD thesis, Department of Social and Economic Geography, Umeå University.

Mattsson, M., and Pettersson, Ö. 2005. Cross-border collaboration in the North: Viewpoints of municipal representatives and firm managers on the Bothnian Arc project. Fennia 183(2):97-107.

Ministry for Rural Affairs. 2013. Reindeer husbandry. http:// www.government/se/sb/d/2160/a/66261. Stockholm: Ministry for Rural Affairs.

Ministry of Agriculture. 2009. The Sami - An indigenous people in Sweden. Information Folder Jo 04.015. Kiruna: The Sami Parliament.

Müller, D.K. 2006. Amenity migration and tourism development in the Tärna Mountains, Sweden. In: Moss, L.A.G., ed. The amenity migrants: Seeking and sustaining mountains and their cultures. Wallingford, United Kingdom: Cabi. 245-258.

- 2011. Tourism development in Europe's "last wilderness": An assessment of nature-based tourism in Swedish Lapland. Chapter 5 in: Grenier, A.A., and Müller, D.K., eds. Polar tourism: A tool for regional development. Montreal: Presses de l'Université du Québec. 129-153.

Müller, D.K., and Ulrich, P. 2007. Tourism development and the rural labour market in Sweden, 1960-1999. In: Müller, D.K., and Jansson, B., eds. Tourism in peripheries: Perspectives from the far North and South. Wallingford, United Kingdom: Cabi. 85-105.

Neumann, I.B. 1996. Russia and the idea of Europe: A study in identity and international relations. London: Routledge.

- 1999. Uses of the other: "The East" in European identity formation. Manchester, United Kingdom: Manchester University Press.

Nordlund, A., and Westin, K. 2011. Forest values and forest management attitudes among private forest owners in Sweden. Forests 2(1):30-50.
Norstedt, G. 2011. Lappskattelanden på Geddas karta: Umeå lappmark från 1671 till 1900-talets början [The real estate units on the maps by Gedda: The Umeå Lapland areas from 1671 until the beginning of the $20^{\text {th }}$ century]. Umeå: Thalassa förlag.

NSPA (Northern Sparsely Populated Areas). 2012. http://www. nspa-network.eu/startsida.aspx.

Paasi, A. 1996. Territories, boundaries and consciousness: The changing geographies of the Finnish-Russian border. Chichester, United Kingdom: John Wiley \& Sons.

Pettersson, Ö. 2001a. Contemporary population changes in north Swedish rural areas. Fennia 179(2):159-173.

2001b. Microregional fragmentation in a Swedish county. Papers in Regional Science 80(4):389-409.

—. 2002. Socio-economic dynamics in sparse regional structures. PhD thesis, Department of Social and Economic Geography, Umeå University.

- 2010. An ageing countryside? Successful ageing or just advanced ageing in the rural areas of northern Sweden? In: Westlund, H., and Kobayashi, K., eds. Social development trends in rural areas, Vol. 5. Jönköping, Sweden: Research Unit for Rural Entrepreneurship and Growth, Jönköping International Business School. 151-167.

Pettersson, R. 2004. Sami tourism in northern Sweden: Supply, demand and interaction. Östersund, Sweden: ETOUR.

Rantakyrö, L. 2008. Labor supply in Pajala and Kolari. Luleå: Department of Human Work Sciences, Luleå University of Technology.

Said, E.W. 1979. Orientalism. New York: Vintage Books.

Sjölander, P. 2011. What is known about the health and the living conditions of the indigenous people of northern Scandinavia, the Sami? Global Health Action 2011, 4: 8457, doi:10.3402/gha. v4i0.8457.

Skogsstyrelsen. 2012. Swedish Statistical Yearbook of Forestry, 2011. Jönköping: Statistics Sweden.

State of Alaska. 2007. Alaska population projections 2007-2030. Fairbanks: Alaska Department of Labor and Workforce Development.

- 2010. Alaska population overview 2007-2008 estimates. Fairbanks: Alaska Department of Labor and Workforce Development.

2012. Alaska population overview: 2010 census and 2011 estimates. Fairbanks: Alaska Department of Labor and Workforce Development.

Statistics Greenland. 2012. Population. Nuuk. http://www.stat.gl/ dialog $/$ main. asp?lang $=$ en $\&$ theme $=$ Population $\&$ link $=$ BE.

Statistics Sweden. 2012. Statistikdatabasen [Statistical database]. http://www.ssd.scb.se/databaser/makro/start.asp.

—. 2013. Regionalräkenskaper [Regional accounts]. http:// www.scb.se/Pages/SSD/SSD_SelectVariables__ 340487. aspx?google $=$ true $\&$ px_tableid $=$ ssd_extern\%3ABRPSysLon SNI2 Ar.

Svevind 2012. Markbygden. http:/Www.svevind.se/Projects/ Project.aspx? projectID=1\&lang=en-US.

Swedish Chair of the Barents Euro-Arctic Council. 2009. Swedish chairmanship of the Barents Euro-Arctic Council, 2009-2011. Kirkenes, Norway: International Barents Secretariat. 
Swedish Department of Foreign Affairs. 2011. Sveriges strategi för den arktiska regionen [Sweden's strategy for the Arctic region]. Stockholm: Department of Foreign Affairs.

Turner, F.J. 1979. The frontier in American history. Huntington, New York: Krieger Publishing.

Waara, P. 1996. Ungdom i gränsland [Youth in the borderland]. Umeå: Boréa.

Westin, K. 2012. Hemma i Norrland: Om identitet och samhörighet med andra [At home in Norrland: On the identity and connectedness with others]. In: Lidström, A., ed. Ett delat Norrland: på väg mot regioner? [A divided Norrland: Moving towards regions?]. Umeå: Statsvetenskapliga institutionen. $127-137$.

Westin, L. 2006. Trading natural resources for public grants: Development rhetoric image and social capital in north Sweden. In: Ito, K., Westlund, H., Kobayashi, K., and Hatori, T., eds. Social capital and development trends in rural areas, Vol. 2. Kyoto: MARG. $71-84$.
Wiberg, U. 2000. Norrland - glest, glesare, glesast [Norrland sparse, sparser, sparsest]. In: Hjelmskog, S., ed. Hemort Sverige [Hometown Sweden]. Norrköping: Integrationsverket. $88-124$.

- 2012. Norrlänningarnas framtidsperspektiv [Northerner future perspectives]. In: Lidström, A., ed. Ett delat Norrland: på väg mot regioner? [A divided Norrland: Moving towards regions?]. Umeå: Statsvetenskapliga institutionen. 175-184.

Wiberg, U., and Lind, T. 2012. Uppfattningar om att leva och bo i nor [Perceptions of life and living in the North]. In: Lidström, A., ed. Ett delat Norrland: på väg mot regioner? [A divided Norrland: Moving towards regions?]. Umeå: Statsvetenskapliga institutionen. $161-173$.

Wiberg, U., Jansson, B., and Lundmark, L. 2002. Ex-post evaluation of Objective 6 programmes for the period 1995-99: Country report for Sweden. EU 2001.CE.16.0.AT.063. Brussels: EU.

Yukon Bureau of Statistics. 2006. Life expectancy in the Yukon, 2006. http://www.eco.gov.yk.ca/pdf/life_expectancy06.pdf. 